\title{
Airway hyperresponsiveness, prevalence of chronic respiratory symptoms, and lung function in workers exposed to irritants
}

\author{
A M Kremer, T M Pal, J S M Boleij, J P Schouten, B Rijcken
}

\author{
University of \\ Groningen, \\ Department of Social \\ Medicine and \\ Epidemiology, Ant \\ Deusinglaan 1, 9713 \\ AV Groningen, The \\ Netherlands \\ A M Kremer \\ T M Pal \\ J P Schouten \\ B Rijcken \\ University of \\ Wageningen, \\ Department of Air \\ Pollution, \\ Wageningen, The \\ Netherlands \\ J S M Boleij \\ Requests for reprints to: \\ B Rijcken, University of \\ Groningen, Department of
Social Medicine and \\ Epidemiology, Ant \\ Deusinglaan 1, 9713 AV \\ Groningen, The \\ Netherlands. \\ Accepted 22 March 1993
}

\begin{abstract}
The association between occupational exposure to airway irritants and the prevalence of chronic respiratory symptoms and level of lung function, and whether these associations were modified by airway hyperresponsiveness, smoking, and a history of allergy were studied in 668 workers from synthetic fibre plants. Respiratory symptoms were recorded with a self administered Dutch version of the British Medical Research Council questionnaire, with additional questions on allergy. Airway responsiveness was measured by a 30 second tidal breathing histamine challenge test. On the basis of job titles and working department, the current state of exposure of all workers was characterised as (1) no exposure, reference group; (2) white collar workers; (3) $\mathrm{SO}_{2} \mathrm{HCl}, \mathrm{SO}_{4}{ }^{2}$; (4) polyester
\end{abstract} vapour; (5) oil mist and vapour; (6) polyamide and polyester vapour; (7) multiple exposure. Workers exposed to airway irritants were not simultaneously exposed to airborne dust. Airway hyperresponsiveness (AHR), defined as a $20 \%$ fall in forced expiratory volume in one second $\left(F E V_{1}\right)$ at $\leqslant 32 \mathrm{mg} / \mathrm{ml}$ histamine, was present in $23 \%$ of the subjects. The association between exposure groups and prevalence of symptoms was estimated by means of multiple logistic regression; the association with level of lung function (forced vital capacity (FVC), FEV, maximum mid-expiratory flow rate (MMEF)) was estimated by means of multiple linear regression. Both methods allow simultaneous adjustment for potential confounding factors. The exposure groups were associated with a higher prevalence of chronic respiratory symptoms. Lower prevalence of symptoms was found for workers exposed to $\mathrm{SO}_{2}, \mathrm{HCl}$, and $\mathrm{SO}_{4}{ }^{2-}$, most likely due to pre-employment selection procedures. Current smoking, AHR, and a history of allergy were significantly associated with a higher prevalence of chronic respiratory symptoms, independent of each other, and independent of irritant exposure. The association between exposure and prevalence of symptoms was greater in smokers than in ex-smokers and nonsmokers. This difference was most clearly seen in the polyester vapour and polyamide and polyester vapour group. No modification of the association between exposure groups and prevalence of symptoms by airway hyperresponsiveness could be shown. The exposure groups were not significantly associated with a lower level of lung function. Adjustment for chronic respiratory symptoms did not change the results. There were no indications of a possible interaction between exposure and AHR, current smoking, or a history of allergy on lung function. Workers of the polyester vapour and the oil mist and vapour group with $>10$ years of exposure had a lower FEV,$(\beta=-295$ and $-358 \mathrm{ml})$ and a significantly lower MMEF $(\beta=-1080$ and $-1247 \mathrm{ml} / \mathrm{s} ; \mathrm{p}<0.05$ ) than the reference group. The number of workers of both groups were, however, small ( $\mathrm{n}=$ 10 and $n=13$ respectively). More investigation is needed to clarify the relations between low level exposure to irritant and respiratory health.

(Occup Environ Med 1994;51:3-13)

Exposure to gases, vapours, and fumes can cause respiratory symptoms and bronchoconstriction by different pathophysiological mechanisms: a direct effect on the irritant receptors in the wall or mucosal inflammation of the bronchus. ${ }^{1}$ Accidental exposure to high concentrations of irritant gases and fumes more commonly results in acute chemical pneumonitis. ${ }^{2} \mathrm{~A}$ reactive airways dysfunction syndrome in which the respiratory symptoms persisted for years after the exposure, has been described after exposure to a single high concentration of an irritant. ${ }^{3}$ Of current interest is whether low exposure to these gases, vapours, and fumes causes respiratory health effects. It has been postulated that pre-existing airway hyperreactivity may enhance the onset of respiratory symptoms and airway obstruction in subjects exposed to occupational irritants. ${ }^{15}$ Also, allergy and cigarette smoking may be related to increased risk of respiratory problems. Whether exposures to irritant gases or fumes at concentrations commonly found in occupational settings result in respiratory diseases has not been studied extensively. ${ }^{6-8} \mathrm{~A}$ study among workers in the Paris area showed that exposures to gases caused an accelerated decline of $\mathrm{FEV}_{1}$ only in 
the presence of simultaneous exposure to heat or dust. ${ }^{9}$ Korn and coworkers found in a general population study that exposures to gas or fumes, after controlling for exposure to dust, was significantly associated with increased prevalence of respiratory symptoms. They also reported that exposure to gases or fumes was associated with an increased prevalence of a decreased $\mathrm{FEV}_{1} / \mathrm{FVC}$ ratio $(<0 \cdot 6)$, but this association was not significant. ${ }^{8}$

To get more insight into the relation between occupational exposures to irritants and obstructive airway disease, we conducted a longitudinal study at synthetic fibre plants among workers having known low level exposure to airway irritants. We also wanted to investigate the role of bronchial hyperreactivity, smoking, and a history of allergy. The purpose of this report is to present the cross sectional findings of the prevalence of chronic respiratory symptoms and level of pulmonary function in workers exposed to occupational airway irritants. We also investigated whether an association between exposure to irritants, respiratory symptoms, and level of lung function was different for subjects with increased airway reactivity, for smokers, and for subjects with a history of allergy. For these analyses, data from the base line study were used.

\section{Methods}

\section{STUDY DESIGN}

The study was designed prospectively and was conducted among workers from synthetic fibre plants that belonged to the same industrial location. The base line survey was performed from April to July 1989, during working days. The study has been approved by the Ethics Board of the Groningen University Hospital and Medical School. Written informed consent was obtained from all participants.

\section{PRODUCTION PROCESS}

The synthetic fibre plants produce polyamid, polyester and para-aramid yarn, and fibres, each product being manufactured in a different department. Polyester is a polycondensation product of dimethylterephthalic acid and ethylene glycol and polyamide is a polycondensation product of caprolactam. The production process of the yarn and fibres consists of polymerisation and polycondensation of the monomers, cutting up of the polymer, melting of the chips, and spinning, winding, stretching, and texturising of the yarn. After spinning, a synthetic oil mixture is applied to the yarn which functions as an emulsifer and lubricant. The tasks are carried out by different groups of workers (no job rotation). The production process of the para-aramid fibres is different. The supplied polymer powder is dissolved in a sulphuric acid solution, after which it is spun. The sulphuric acid is washed out and neutralised. The yarn is dried, wound, and texturised. The polymerisation is not done at the para-aramid plant, but at another location. The process from dissolving the polymer up to the spinning is fully automated and takes place in separate production halls. The rest of the process takes place in one production hall.

STUDY POPULATION AND EXPOSURE GROUPS Male employees from departments with potential exposure to airway irritants and a control group from departments presumed to be free from exposure were invited to participate in the survey. In May 1989 the total number of workers eligible for investigation was 909 men.

On the basis of job titles and working department at the time of the survey, the current exposure state of all workers was characterised. The workers were divided into seven groups.

(1) Reference group - This group consisted of workers of the forwarding department, the reelers of the industrial yarn plant, and the texturisers of the carpet yarn plant. These workers were not subjected to exposure to airway irritants.

(2) White collar group-This consisted of clerical workers and workers who were not directly involved in the production of the yarn and fibres (for example, process technologists, production instructors, production floor managers) and were not included in the reference group because of a different social or working background..$^{10}$

(3) $\mathrm{SO}_{2}, \mathrm{SO}_{4}{ }^{2-}, \mathrm{HCl}$ group-This group consisted of production line workers and maintenance and instrumentation fitters who could have been exposed to $\mathrm{SO}_{2}$ and $\mathrm{HCl}$ vapour and $\mathrm{SO}_{4}{ }^{2-}$ and $\mathrm{HCl}$ aerosols, generated during the production of the para-aramid fibre. Personal sampling (seven hour time weighted average) showed maximum concentrations of $\mathrm{SO}_{2}$ vapour of $0.30 \mathrm{mg} / \mathrm{m}^{3}$, of $\mathrm{HCl}$ aerosols of $2.1 \mathrm{mg} / \mathrm{m}^{3}$ and of $\mathrm{SO}_{4}{ }^{2-}$ aerosols of 0.5 $\mathrm{mg} / \mathrm{m}^{3}$. For certain work operations peak exposures occur up to $40 \mathrm{mg} / \mathrm{m}^{3} \mathrm{HCl}$ vapour (averaging time a few minutes) and up to 46 $\mathrm{mg} / \mathrm{m}^{3} \mathrm{SO}_{2}$ vapour (averaging time a few seconds). During texturising of the yarn, exposure to airborne para-aramide fibres is possible. Monitoring of personal exposure to airborne para-aramide fibres over a four year period showed maximum five hour time weighted average concentrations of 0.11 respirable fibres $/ \mathrm{cm}^{3}$.

(4) Polyester vapour group-This group consisted of workers of the polyester chip department who were involved in the polymerisation and polycondensation of the monomers of dimethylterephthalic acid and glycol and cutting up of the polyester polymer. Because of the high temperature $\left(>250^{\circ} \mathrm{C}\right)$ during the polycondensation, some thermodegradation of the polymer can occur. Workers can be exposed to thermodegradation products like aldehyde vapours, and to diphenyl diphenyloxide (used as a heat transfer agent) vapour. Personal sampling showed maximum five hour time weighted average concentrations of total aldehyde vapour of $0.04 \mathrm{mg} / \mathrm{m}^{3}$, primarily consisting of acetaldehyde. No aldehyde exposure could be 
detected (average time 30 minutes). Personal sampling of diphenyl diphenyloxide exposure showed eight hour time weighted average concentrations up to $7.3 \mathrm{mg} / \mathrm{m}^{3}(\mathrm{n}=29$; geometric mean (GM) $2.2 \mathrm{mg} / \mathrm{m}^{3}$ ) under normal conditions and as a result of an incident up to $48.1 \mathrm{mg} / \mathrm{m}^{3}$ ( $\left.\mathrm{n}=14 ; \mathrm{GM} 8.5 \mathrm{mg} / \mathrm{m}^{3}\right)$. For certain operations peak exposures to diphenyl diphenyloxide occur; monitoring (averaging time 30 seconds) showed peak exposures up to $60 \mathrm{mg} / \mathrm{m}^{3}$. Also, during certain operations (process temperatures around $250^{\circ} \mathrm{C}$ ) and as a result of a leak, workers can be exposed to ethylene glycol vapour.

(5) Oil mist and oil vapour group-This group was composed of the workers who were involved in winding and stretching (spindraw-winders) of industrial yarn (polyester and polyamide) and of the workers of the spin-draw-winding and texturising carpet yarn department. There was exposure to oil mist and oil vapour emanating from the synthetic oil mixture that is applied to the yarn. Monitoring (average time 20-30 seconds) near the machines showed respirable oil aerosols up to $1.1 \mathrm{mg} / \mathrm{m}^{3}$ in normal situations and up to $4.4 \mathrm{mg} / \mathrm{m}^{3}$ during interruptions. Because the yarn is heated (around $180^{\circ} \mathrm{C}$ ), some thermodegradation of components of the oil can occur. The air in the area of one of the three production lines of the winding and stretching department is humidified with a steam humidification system. The air in the area of the other two lines and the air of the spin-draw-winding and texturising department is humidified with a cold water spray system. Exposure to airborne viable materials from the cold water spray system was possible. Results of an occupational exposure study showed low concentrations of airborne Gram negative bacteria ( $n=6$; $\mathrm{GM}$ 47 colony forming units (cfu) $/ \mathrm{m}^{3}$ ), of fungi ( $\mathrm{n}$ $=6$; GM $7.5 \mathrm{cfu} / \mathrm{m}^{3}$ ), and of personal exposure to endotoxin $\left(\mathrm{n}=5 ; \mathrm{GM} 64 \mathrm{pg} / \mathrm{m}^{3}\right)$. $^{11}$

(6) Polyamide and polyester vapour group-This group consisted of the spinners of the industrial yarn plant who were involved in spinning of the melted polyamide and polyester chips to yarn and in exchanging spinning garnitures. Because of the high temperature of the production process $\left(>200^{\circ} \mathrm{C}\right)$ thermodegradation products of the polyamide and polyester polymer could arise. Spinners can be exposed to vapours of these products-for example, oligomers-and to lactam vapour, measurements near the machines showed 150 minute time weighted average concentrations of lactam vapour with a GM of $15.9 \mathrm{mg} / \mathrm{m}^{3}$ $(\mathbf{n}=3)$.

Personal sampling showed that both the oil mist $(n=6)$ and the polyamide and polyester vapour group $(n=26)$ were exposed to low concentrations of diphenyl diphenyloxide (eight hour time weighted average; GM 0.2 $\mathrm{mg} / \mathrm{m}^{3}$ ) and for both groups exposure to aldehyde vapour was of the same order of magnitude, independent of function tasks $(n=25$; eight hour time weighted average, GM $8 \cdot 4$ $\mathrm{mg} / \mathrm{m}^{3}$ ).

(7) Multiple exposures group-This group con- sisted of maintenance engineers. They were exposed to different airway irritants depending on location within the plant (oil mist and oil vapour, aldehyde and oligomer vapours, lactam, and soldering fumes, but no acid aerosols).

\section{QUESTIONNAIRE}

Data on smoking habits and respiratory symptoms were collected by means of a self administered Dutch version of the British Medical Research Council standardised questionnaire. Additional questions about work related respiratory symptoms, allergy, and work history were included. Subjects were considered to have symptoms if they had cough or phlegm production on most days or nights for as much as three consecutive months each year during winter (chronic cough or chronic phlegm), if during the previous three years they experienced more than one period of at least three weeks with (increased) cough and phlegm (episodes of bronchitis), if they become short of breath when walking with other people of their own age on level ground (dyspnoea $\geqslant$ grade III), if their chest sounded wheezing or whistling more than once a year (frequent wheeze), or if they ever had attacks of shortness of breath with wheezing (asthmatic attacks). Nose catarrh is defined as being troubled with a clogged or runny nose or sneezing for as much as three consecutive months each year. Subjects were considered allergic if they answered yes to one of the following two questions: Have you ever had hay fever? Do you get eye, nose, or respiratory symptoms if you are exposed to house dust, domestic animals, or fungi?

Non-smokers are defined as lifelong nonsmokers. Ex-smokers are those who stopped at least one month before the examination. Current smokers are defined as those who smoked one cigarette or more a day for at least one year. Smoking habit as a continuous variable is expressed as pack-years. This is the product of the number of years a person has smoked and the packs of cigarettes (25 cigarettes) smoked a day. The cigar consumption was recalculated to pack-years. It was assumed that a small cigar is equal to two cigarettes and a big cigar is equal to five cigarettes.

\section{SPIROMETRY}

Spirometry was performed from Monday to Friday between 08.30 and 16.00 such that for each department the measurements were equally distributed over the time of the day, the working week, the shifts, and the survey period. Spirometry was performed with a water sealed spirometer (2400 Pulmonary Function Laboratory; SensorMedics BV, Bilthoven, NL) with automatic data processing (IBM-AT computer). A minimum of three satisfactory forced expiratory manoeuvres was required of each subject. A satisfactory test required that of two manoeuvres the forced vital capacity (FVC) was reproducible within $5 \%$ with a maximum of $300 \mathrm{ml}^{12}$ 
Measurements were corrected for body temperature, atmospheric pressure, and water saturation (BTPS). Analyses were performed on the largest FVC, forced expiratory flow in one second $\left(\mathrm{FEV}_{1}\right)$ and the forced expiratory flow between $25 \%$ and $75 \%$ points of the FVC curve (MMEF). The FEV 1 was also expressed as a percentage of predicted value $\left(\% \mathrm{FEV}_{1}\right)$ with the prediction equations of Quanjer and colleagues. ${ }^{12}$

\section{HISTAMINE CHALLENGE TEST}

Airway responsiveness was measured by a histamine challenge test. Initial $\mathrm{FEV}_{1}$ was the highest prechallenge $\mathrm{FEV}_{1}$. Subjects with cardiovascular disease or lung disease requiring daily medication were not permitted to perform the test. Subjects with a prechallenge $\mathrm{FEV}_{1}$ below $80 \%$ of the predicted value were also excluded. The basic protocol was the De Vries modification of the 30 second tidal breathing method: after a pretest with saline, subjects inhaled sequential aerosols of histamine biphosphate in concentrations of 1,2 , $4,8,16$, and $32 \mathrm{mg} / \mathrm{ml} .^{13}$ At 30 and $90 \mathrm{sec}-$ onds after each concentration subjects performed an $\mathrm{FEV}_{1}$ manoeuvre. The test was ended if there was a decrease in $\mathrm{FEV}_{1}$ of at least $18 \%$, or if the highest concentration had been given. Subjects with a history of asthma like symptoms, or allergy, or with a fall in $\mathrm{FEV}_{1}$ after saline of $6 \%$ or more started with $1 \mathrm{mg} / \mathrm{ml}$. All other subjects started with 4 $\mathrm{mg} / \mathrm{ml}$. Quadrupling histamine concentrations were given until the $\mathrm{FEV}_{1}$ had fallen at least $6 \%$, then the schedule was changed to doubling concentrations. A software program, Broncho-Challenge (SensorMedics BV), was used for recording the results of the $\mathrm{FEV}_{1}$ values of the histamine challenge test.

The provocation concentration causing a $20 \%$ fall in $\mathrm{FEV}_{1}$ (the $\mathrm{PC}_{20}$ ) was calculated by log linear interpolation of the last two data points, with extrapolation up to one doubling concentration (maximum $64 \mathrm{mg} / \mathrm{ml}$ ). The threshold value was defined as the concentration by which the subject would have experienced a fall in $\mathrm{FEV}_{1}$ of $20 \%$ or more. Airway hyperresponsiveness was defined as a $20 \%$ fall in $\mathrm{FEV}_{1}$ at $32 \mathrm{mg} / \mathrm{ml}$ of histamine or less. In the analyses airway responsiveness is considered as a dichotomous variable with threshold values $\leqslant 32 \mathrm{mg} / \mathrm{ml}$ and $\geqslant 64 \mathrm{mg} / \mathrm{ml}$ of histamine.

\section{DATA ANALYSIS}

Statistical significance of the unadjusted differences in symptom prevalence between groups in contingency tables was assessed by $\chi^{2}$ analysis. A p value of $<0.05$ was considered significant. The association between exposure to airway irritants and respiratory symptoms was measured by multiple logistic regression. This method allows simultaneous adjustment for potential confounding factors such as age, smoking habit, airway responsiveness, and history of allergy. The odds ratio (OR) of a category relative to the reference category was estimated by taking the antilog of the coefficient of that category. The additional effect of the combination of two variables was assessed by including interaction terms in the model. For a continuous variable, the $\mathrm{OR}$ is an estimate of change in log odds per unit of measurement. The $95 \%$ confidence intervals (95\% CIs) were given for ORs. An OR was significant if the $95 \%$ CI did not include unity.

The differences in means for \%FVC, $\% \mathrm{FEV}_{1}$ and $\% \mathrm{MMEF}$ predicted were tested by a two tailed $t$ test, and p values $<0.05$ were considered significant. The association between exposure to airway irritants and level of lung function was investigated with multiple linear regression. This method also allows simultaneous adjustment for covariates such as age, smoking habit, airway responsiveness, and a history of allergy. To adjust for the effect of smoking and age on lung function, several indices of smoking habit and age were examined. We examined smoking as a categorical, an ordinal, and a continuous variable. Of these, the continuous variables pack-years and smoking duration explained the largest amount of variance of the regression model (largest adjusted $\mathbf{R}^{2}$ ). Pack-years were used in the analyses. We examined age, age ${ }^{2}$ and (age $+\mathrm{age}^{2}$ ). $\mathrm{Age}^{2}$ and (age $+\mathrm{age}^{2}$ ) explained more of the variance than age. We chose (age + age $^{2}$ ) because the decrease of lung function with age may be larger in older than in younger subjects. ${ }^{14}$ Also (age + age $^{2}$ ) may provide a better modelling of the turnover from lung function growth to decline. ${ }^{15}$ The described relations are considered significant at $\mathrm{p}$ values $<0.05$.

The analyses were performed with the Superior Performing Software System/PC + (SPSS, Inc, Chicago) program (version 4.0).

\section{Results}

Of the 909 men who were invited, 790 (87\%) took part in the study. Of these, 28 were excluded because of different cultural or racial backgrounds. Of the remaining 762 , 680 gave an acceptable histamine challenge test. Forty three had no test because they did not meet the inclusion criteria and eight had no test for miscellaneous reasons, 11 had incomplete data and for 20 the quality of the test was poor. Of the remaining 680 men 12 could not be included because of incomplete data on smoking or lung function. Thus, data from 668 men were used for the analyses.

The study population was young, with $50 \%$ of the subjects younger than 31 (range 20-58); (table 1). Current smoking ranged from $44 \%$ in the $\mathrm{SO}_{2}$ and multiple exposure group to $61 \%$ in the polyamide and polyester vapour group. The amount of pack-years was on average higher among the older exposure groups. Airway hyperresponsiveness was present in $23 \%$ of the subjects. The prevalence was low in the $\mathrm{SO}_{2}(18 \%)$ and the oil mist group $(18 \%)$. The prevalence of a history of allergy was $14 \%$ for the non-smokers, $15 \%$ for the ex-smokers, and $12 \%$ for the smokers. Thirty four percent of the subjects with a history of allergy also had airway hyperrespon- 
Table 1 Characteristics of the study population stratified by exposure group

\begin{tabular}{|c|c|c|c|c|c|c|c|c|}
\hline & $\begin{array}{l}\text { Reference } \\
(n=180)\end{array}$ & $\begin{array}{l}\text { White collar } \\
(n=58)\end{array}$ & $\begin{array}{l}\mathrm{SO}_{2} \mathrm{HCl} \\
\mathrm{SO}_{4}^{2-} \\
(n=119)\end{array}$ & $\begin{array}{l}\text { Polyester } \\
\text { vapour } \\
(n=94)\end{array}$ & $\begin{array}{l}\text { Oil mist } \\
\text { vapour } \\
(n=141)\end{array}$ & $\begin{array}{l}\text { Polyamide and } \\
\text { polyester vapour } \\
(n=51)\end{array}$ & $\begin{array}{l}\text { Multiple } \\
\text { exposure } \\
(n=25)\end{array}$ & $\begin{array}{l}\text { Total } \\
(n=668)\end{array}$ \\
\hline $\begin{array}{l}\text { Age (y, mean (range)) } \\
\text { Height (cm (SD)) }\end{array}$ & $\begin{array}{l}31 \cdot 1(20-56) \\
180 \cdot 9(6 \cdot 2)\end{array}$ & $\begin{array}{l}43.9(27-58) \\
178.9(6.6)\end{array}$ & $\begin{array}{l}30 \cdot 8(22-57) \\
182 \cdot 8(6 \cdot 4)\end{array}$ & $\begin{array}{l}32 \cdot 7(22-55) \\
182 \cdot 1(6 \cdot 9)\end{array}$ & $\begin{array}{l}31 \cdot 2(22-58) \\
180 \cdot 6(5 \cdot 7)\end{array}$ & $\begin{array}{l}36 \cdot 2(22-56) \\
177 \cdot 8(7 \cdot 1)\end{array}$ & $\begin{array}{l}36 \cdot 5(23-53) \\
177 \cdot 7(6 \cdot 0)\end{array}$ & $\begin{array}{l}33.0(20-58) \\
180.8(6.5)\end{array}$ \\
\hline $\begin{array}{l}\text { Duration of total } \\
\text { employment }(y(S D)) \\
\text { Years in current }\end{array}$ & $7 \cdot 0(7 \cdot 3)$ & $17.0(7.9)$ & $6 \cdot 3(5 \cdot 2)$ & $8.0(6.5)$ & $7 \cdot 0(6 \cdot 3)$ & $10 \cdot 3(8 \cdot 0)$ & $13.4(10.4)$ & $8 \cdot 4(7 \cdot 5)$ \\
\hline $\begin{array}{l}\text { exposure group: } \\
\leqslant 2(\mathrm{n}(\%)) \\
>2-\leqslant 5 \\
>5-\leqslant 10 \\
>10 \\
\text { Smoking habit }(\mathrm{n}(\%)) \text { : }\end{array}$ & $\begin{array}{l}68(38) \\
62(34) \\
35(19) \\
15(8)\end{array}$ & $\begin{array}{r}12(21) \\
26(45) \\
11(19) \\
9(16)\end{array}$ & $\begin{array}{l}39(33) \\
77(65) \\
3(3) \\
-\end{array}$ & $\begin{array}{l}13(14) \\
44(47) \\
27(29) \\
10(11)\end{array}$ & $\begin{array}{l}58(41) \\
48(34) \\
22(16) \\
13(9)\end{array}$ & $\begin{array}{r}11(22) \\
18(35) \\
13(25) \\
9(18)\end{array}$ & $\begin{array}{r}\overline{12}(48) \\
6(24) \\
7(28)\end{array}$ & $\begin{array}{c}201(30) \\
287(43) \\
117(18) \\
63(9)\end{array}$ \\
\hline $\begin{array}{l}\text { Non-smokers } \\
\text { Ex-smokers } \\
\text { Smokers } \\
\text { Pack-years } \\
\text { Allergy (n (\%)) } \\
\text { Airway hyper- }\end{array}$ & $\begin{array}{c}54(30) \\
26(14) \\
100(56) \\
6 \cdot 8(8 \cdot 2) \\
22(12)\end{array}$ & $\begin{array}{l}3(5) \\
21(36) \\
34(59) \\
21 \cdot 2(11 \cdot 7) \\
7(12)\end{array}$ & $\begin{array}{l}35(29) \\
32(27) \\
52(44) \\
8 \cdot 4(7 \cdot 7) \\
17(14)\end{array}$ & $\begin{array}{l}19(20) \\
28(30) \\
47(50) \\
6 \cdot 4(6 \cdot 3) \\
12(13)\end{array}$ & $\begin{array}{l}24(17) \\
32(23) \\
85(60) \\
10 \cdot 8(8 \cdot 5) \\
18(13)\end{array}$ & $\begin{array}{l}6(12) \\
14(28) \\
32(63) \\
15 \cdot 0(10 \cdot 2) \\
4(8)\end{array}$ & $\begin{array}{l}6(24) \\
8(32) \\
11(44) \\
13 \cdot 3(9 \cdot 7) \\
7(28)\end{array}$ & $\begin{array}{l}147(22) \\
161(24) \\
360(54) \\
11 \cdot 2(9 \cdot 5) \\
87(13)\end{array}$ \\
\hline $\begin{array}{l}\text { responsiveness (n (\%)) } \\
\% \text { FEV }_{1} \text { (predicted (SD)) } \\
\text { FVC (1 (SD)) } \\
\text { FEV } 1 \text { (1 (SD)) } \\
\text { MMEF (1/s (SD)) }^{\text {MMEF }}\end{array}$ & $\begin{array}{c}47(26) \\
104 \cdot 6(11.7) \\
5.655(0.718) \\
4.575(0.643) \\
4.620(1.310)\end{array}$ & $\begin{array}{l}15(26) \\
105 \cdot 3(12 \cdot 6) \\
5 \cdot 233(0 \cdot 848) \\
4 \cdot 144(0 \cdot 719) \\
4 \cdot 123(1 \cdot 327)\end{array}$ & $\begin{array}{l}21(18) \\
106 \cdot 1(10.6) \\
5 \cdot 878(0.793) \\
4.750(0.633) \\
4.747(1.232)\end{array}$ & $\begin{array}{l}26(28) \\
103.8(11 \cdot 7) \\
5.668(0.795) \\
4.552(0.665) \\
4.434(1.292)\end{array}$ & $\begin{array}{l}25(18) \\
104.5(11.8) \\
5.636(0.715) \\
4.557(0.664) \\
4.522(1.230)\end{array}$ & $\begin{aligned} 12(24) \\
103 \cdot 9(11 \cdot 3) \\
5 \cdot 334(0 \cdot 826) \\
4 \cdot 270(0 \cdot 710) \\
4 \cdot 221(1 \cdot 188)\end{aligned}$ & $\begin{array}{c}5(20) \\
106 \cdot 3(12 \cdot 0) \\
5 \cdot 348(0 \cdot 742) \\
4.338(0 \cdot 622) \\
4.442(1 \cdot 149)\end{array}$ & $\begin{array}{l}151(23) \\
104.8(11 \cdot 6) \\
5.620(0 \cdot 783) \\
4.530(0 \cdot 679) \\
4.530(1.286)\end{array}$ \\
\hline
\end{tabular}

siveness. On average, the subjects who were excluded from further analyses were older $(37 \cdot 3(12 \cdot 1)$, had a higher prevalence of never smoking (27\%) and ex-smoking (28\%), a lower prevalence of a history of allergy (7\%) and a lower $\% \mathrm{FEV}_{1}$ predicted $(93.1 \%(14 \cdot 7)$ than those of the study population.

\section{RESPIRATORY SYMPTOMS}

Compared with the reference group, the prevalence rate of any symptom was higher in the polyester vapour, the oil mist and vapour, the polyamide and polyester vapour, and the multiple exposure groups, and lower in the $\mathrm{SO}_{2}$ group (table 2). In general, a higher prevalence of symptoms was significantly associated with current smoking, airway hyperresponsiveness, and a history of allergy.

To estimate the association of the various exposure groups with the presence of respiratory symptoms, multiple logistic regression with simultaneous adjustment for potential confounding factors was used (table 3 ). No differences in prevalence of respiratory symptoms were found between the white collar group and the reference group (OR for any symptom 1-0). Compared with the reference group, workers exposed to $\mathrm{SO}_{2}, \mathrm{HCl}$, and $\mathrm{SO}_{4}{ }^{2-}$ had a lower prevalence (OR for any symptom $0 \cdot 6$ ), and workers exposed to polyester vapour had a higher prevalence of chronic symptoms. Workers exposed to oil mist and vapour had a higher prevalence of chronic cough (OR 2.4), wheeze (OR 1.8), and ever asthmatic attacks (OR $2 \cdot 2$ ), workers exposed to polyamide and polyester vapour had a significantly higher prevalence of cough (OR 5.4), dyspnoea (OR 6.1), and wheeze (OR 3.0), and the engineers with multiple exposures had significantly more episodes of bronchitis (OR 3.5). The prevalence of nasal catarrh did not differ between the exposure groups.

We also investigated whether the associations between the exposure groups and a higher prevalence of respiratory symptoms were influenced by the level of lung function. The logistic regression analysis of table 3 was repeated with additional adjustment for $\% \mathrm{FEV}_{1}$ predicted. Low $\% \mathrm{FEV}_{1}$ was

Table 2 Prevalence of respiratory symptoms stratified by exposure group, smoking habit, allergy history, and airway hyperresponsiveness

\begin{tabular}{|c|c|c|c|c|c|c|c|c|c|}
\hline & $n(100 \%)$ & $\begin{array}{l}\text { Chronic } \\
\text { cough } \\
n(\%)\end{array}$ & $\begin{array}{l}\text { Chronic } \\
\text { phlegm } \\
n(\%)\end{array}$ & $\begin{array}{l}\text { Bronchitis } \\
\text { episodes } \\
n(\%)\end{array}$ & $\begin{array}{l}\text { Dyspnoea } \\
\geqslant \text { grade III } \\
n(\%)\end{array}$ & $\begin{array}{l}\text { Frequent } \\
\text { wheeze } \\
n(\%)\end{array}$ & $\begin{array}{l}\text { Asthmatic } \\
\text { attacks } \\
n(\%)\end{array}$ & $\begin{array}{l}\text { Any } \\
\text { symptom* } \\
n(\%)\end{array}$ & $\begin{array}{l}\text { Nasal } \\
\text { catarrh } \\
n(\%)\end{array}$ \\
\hline \multicolumn{10}{|l|}{ Exposure group: } \\
\hline Reference & 180 & $4(2)$ & $14(8)$ & $22(12)$ & $4(2)$ & $18(10)$ & $9(5)$ & $43(24)$ & $56(20)$ \\
\hline White collars & 58 & $1(2)$ & & 7 (13) & $1(2)$ & $8(14)$ & $2(3)$ & $14(24)$ & $9(16)$ \\
\hline $\mathrm{SO}_{2} \mathrm{HCL} \mathrm{SO}_{4}{ }_{4-}^{2-}$ & 119 & $2(2)$ & $2(2)$ & $10(8)$ & $1(1)$ & $7(6)$ & $1(1)$ & $17(14)$ & $13(11)$ \\
\hline Polyester vapour & 94 & $3(3)$ & $6(6)$ & $15(16)$ & - & $12(13)$ & $2(2)$ & $27(29)$ & $21(22)$ \\
\hline Oil mist and vapour & 141 & $8(6)$ & $10(7)$ & $22(16)$ & $2(1)$ & $22(16)$ & $12(9)$ & $45(32)$ & $29(21)$ \\
\hline Polyamide and & & & & & & & & & \\
\hline Multiple exposures & 25 & $1(4)$ & $2(8)$ & $8(32)$ & - & $3(12)$ & $1(4)$ & $10(40)$ & $5(20)$ \\
\hline \multicolumn{10}{|l|}{ Smoking habit: } \\
\hline Non-smokers & 147 & $1(1)$ & $5(3)$ & $17(12)$ & $3(2)$ & $6(4)$ & $6(4)$ & $23(16)$ & $17(12)$ \\
\hline Ex-smokers & 161 & $1(1)$ & $5(3)$ & $11(7)$ & $2(1)$ & $9(6)$ & $5(3)$ & 18 (11) & 18 (11) \\
\hline Current smokers & 360 & $23(6)$ & $32(9)$ & 65 (18) & 9 (3) & $67(17)$ & $17(5)$ & $109(30)$ & $87(24)$ \\
\hline \multicolumn{10}{|l|}{ Allergy: } \\
\hline Negative & 581 & $19(3)$ & $33(6)$ & $70(12)$ & $12(2)$ & $62(11)$ & $18(3)$ & $142(24)$ & $86(15)$ \\
\hline Positive & 87 & $6(7)$ & $9(10)$ & $23(27)$ & $2(2)$ & $20(23)$ & $10(12)$ & $34(39)$ & $36(42)$ \\
\hline \multicolumn{10}{|l|}{ Airway hyperresponsiveness: } \\
\hline $\begin{array}{l}\text { No } \\
\text { Yes }\end{array}$ & $\begin{array}{l}517 \\
151\end{array}$ & $\begin{array}{r}18(4) \\
7(5)\end{array}$ & $\begin{array}{l}32(6) \\
10(7)\end{array}$ & $\begin{array}{l}68(13) \\
25(17)\end{array}$ & $\begin{array}{l}6(1) \\
8(5)\end{array}$ & $\begin{array}{l}46(9) \\
36(24)\end{array}$ & $\begin{array}{l}13(3) \\
15(10)\end{array}$ & $\begin{array}{r}103(20) \\
47(31)\end{array}$ & $\begin{array}{l}89(17) \\
33(22)\end{array}$ \\
\hline
\end{tabular}

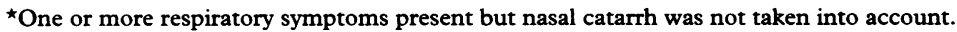


Table 3 Estimated ORs (95\% CIs) for the prevalence of respiratory symptoms by exposure.group, smoking habit, airway responsiveness, and a history of allergy: reference categories were the reference group, non-smokers, normal airway responsiveness, and non-allergic

\begin{tabular}{|c|c|c|c|c|c|c|c|c|}
\hline & $\begin{array}{l}\text { Chronic } \\
\text { cough } \\
(n=25)\end{array}$ & $\begin{array}{l}\text { Chronic } \\
\text { phlegm } \\
(n=42)\end{array}$ & $\begin{array}{l}\text { Bronchitis } \\
\text { episodes } \\
(n=93)\end{array}$ & $\begin{array}{l}\text { Dyspnoea } \\
\geqslant \text { grade-LII } \\
(n=14)\end{array}$ & $\begin{array}{l}\text { Frequent } \\
\text { wheeze } \\
(n=82)\end{array}$ & $\begin{array}{l}\text { Asthmatic } \\
\text { attacks } \\
(n=28)\end{array}$ & $\begin{array}{l}\text { Any } \\
\text { symptomt } \\
(n=176)\end{array}$ & $\begin{array}{l}\text { Nasal } \\
\text { catarrh } \\
(n=122)\end{array}$ \\
\hline $\begin{array}{l}\text { Exposure group: } \\
\text { White collar } \\
\mathrm{SO}_{2} \mathrm{SO}_{4}^{2-} \mathrm{HCl} \\
\text { Polyester }\end{array}$ & $\begin{array}{l}0.4(0.0-4 \cdot 0) \\
1.0(0.2-5 \cdot 5)\end{array}$ & $\overline{0.2}(0 \cdot 1-1 \cdot 0)^{\star}$ & $\begin{array}{l}1.2(0.4-3.3) \\
0.7(0.3-1.5)\end{array}$ & $\begin{array}{l}0.5(0.0-6.0) \\
0.5(0.1-4.6)\end{array}$ & $\begin{array}{l}1.0(0.4-2.8) \\
0.7(0.3-1.8)\end{array}$ & $\begin{array}{l}0.8(0.1-4.4) \\
0.2(0.0-1.3)\end{array}$ & $\begin{array}{l}1.0(0.5-2.3) \\
0.6(0.3-1.2)\end{array}$ & $\begin{array}{l}0.9(0.4-2.2) \\
0.5(0.2-1.0)\end{array}$ \\
\hline $\begin{array}{l}\text { vapour } \\
\text { Oil mist and }\end{array}$ & $1.6(0.3-7 \cdot 7)$ & $0.8(0.3-2.3)$ & $1.5(0.7-3 \cdot 1)$ & - & $1.5(0.6-3.3)$ & $0.4(0 \cdot 1-2 \cdot 1)$ & $1.5(0.8-2.7)$ & $1 \cdot 3(0.7-2 \cdot 5)$ \\
\hline $\begin{array}{l}\text { vapour } \\
\text { Polyamide and }\end{array}$ & $2.4(0.7-8.5)$ & $0.8(0.4-2.0)$ & $1.3(0.7-2.5)$ & $0.7(0 \cdot 1-4 \cdot 1)$ & $1.8(0.9-3.7)$ & $2 \cdot 2(0.9-5.7)$ & $1.6(1.0-2 \cdot 8)$ & $1.1(0.6-1.9)$ \\
\hline $\begin{array}{l}\text { vapour } \\
\text { Multiple }\end{array}$ & $5 \cdot 4(1 \cdot 4-22 \cdot 0)^{\star}$ & $2 \cdot 2(0 \cdot 8-5 \cdot 7)$ & $1 \cdot 8(0 \cdot 7-4 \cdot 2)$ & $6 \cdot 1(1.5-24 \cdot 0)^{\star}$ & $3 \cdot 0(1 \cdot 2-7 \cdot 2)^{\star}$ & $0.5(0.1-3.9)$ & $2 \cdot 3(1 \cdot 2-4 \cdot 7)^{\star}$ & $1 \cdot 1(0 \cdot 5-2 \cdot 6)$ \\
\hline $\begin{array}{l}\text { exposures } \\
\text { Age (y) } \\
\text { Smoking habit: }\end{array}$ & $\begin{array}{l}1.7(0 \cdot 2-17 \cdot 0) \\
1.06(1 \cdot 01-1 \cdot 12)^{\star}\end{array}$ & $\begin{array}{l}1.0(0.2-4 \cdot 8) \\
1.01(0.97-1.06)\end{array}$ & $\begin{array}{l}3.5(1.3-9.7)^{\star} \\
1.00(0.97-1.03)\end{array}$ & $\overline{1.04}(0.97-1.11)$ & $\begin{array}{l}1.4(0.6-3.3) \\
1.03(1.00-1.06)^{\star}\end{array}$ & $\begin{array}{l}0.6(0.1-6.0) \\
0.99(0.95-1.05)\end{array}$ & $\begin{array}{l}2 \cdot 6(1.0-6 \cdot 5)^{\star} \\
1.00(0.98-1.03)\end{array}$ & $\begin{array}{l}1.0(0.3-3.0) \\
0.99(0.96-1.02)\end{array}$ \\
\hline $\begin{array}{l}\text { Ex-smoker } \\
\text { Smoker } \\
\text { Airway hyper- }\end{array}$ & $\begin{array}{l}0.5(0 \cdot 0-8 \cdot 7) \\
8 \cdot 5(1 \cdot 1-65)^{\star}\end{array}$ & $\begin{array}{l}0.9(0 \cdot 2-3 \cdot 3) \\
2 \cdot 7(1 \cdot 0-7 \cdot 3)^{\star}\end{array}$ & $\begin{array}{l}0.5(0.2-1.2) \\
1.7(0.9-3.1)\end{array}$ & $\begin{array}{l}0.5(0.1-3 \cdot 8) \\
0.9(0.2-11 \cdot 9)\end{array}$ & $\begin{array}{l}1 \cdot 0(0 \cdot 3-3 \cdot 0) \\
4.9(2 \cdot 0-11 \cdot 9)^{\star \star}\end{array}$ & $\begin{array}{l}0.8(0 \cdot 2-3 \cdot 1) \\
1.0(0.4-2 \cdot 8)\end{array}$ & $\begin{array}{l}0 \cdot 6(0 \cdot 3-1 \cdot 1) \\
2 \cdot 4(1 \cdot 5-4 \cdot 0)^{\star \star}\end{array}$ & $\begin{array}{l}1 \cdot 0(0 \cdot 5-2 \cdot 1) \\
2 \cdot 6(1 \cdot 5-4 \cdot 7)^{\star \star}\end{array}$ \\
\hline $\begin{array}{l}\text { ness } \\
\text { Allergy }\end{array}$ & $\begin{array}{l}1.1(0.4-2 \cdot 7) \\
3.6(1.3-10 \cdot 2)^{\star}\end{array}$ & $\begin{array}{l}0.9(0.4-1.9) \\
2.3(1.0-5 \cdot 1)^{\star}\end{array}$ & $\begin{array}{l}1.2(0.7-2.0 \\
2.9(1.6-5 \cdot 1)^{\star \star}\end{array}$ & $\begin{array}{l}4.61 .5-14.5)^{\star \star} \\
1.3(0.3-6.8)\end{array}$ & $\begin{array}{l}2.9(1.7-4.8)^{\star \star} \\
3.2(1.7-6.0)^{\star \star}\end{array}$ & $\begin{array}{l}4.3(1.9-9.7)^{\star \star} \\
3.8(1.6-8.8)^{\star \star}\end{array}$ & $\begin{array}{l}2 \cdot 1(1 \cdot 4-3 \cdot 2)^{\star \star} \\
2 \cdot 1(1 \cdot 3-3 \cdot 6)^{\star \star}\end{array}$ & $\begin{array}{l}1 \cdot 1(0 \cdot 7-1 \cdot 7) \\
4 \cdot 8(2 \cdot 8-8 \cdot 0)^{\star \star}\end{array}$ \\
\hline
\end{tabular}

${ }^{\star} \mathrm{p}<0.05 ;{ }^{\star \star} \mathrm{p}<0.01 ;$

fOne or more of the respiratory symptoms present, but nasal catarrh excluded.

significantly associated with a higher prevalence of any symptom (OR $0.96 ; 95 \%$ CI 0.95-0.98). Compared with the results of table 3, the ORs for the exposure groups remained essentially the same.

Age (table 3) was associated with a higher prevalence of chronic cough (OR 1.06), dyspnoea (OR 1.04), and wheeze (OR 1.03), but not with any symptom (OR 1.00). Smokers, subjects with airway hyperresponsiveness, and subjects with a history of allergy reported significantly more respiratory symptores with respective ORs for any symptom of $2 \cdot 4,2 \cdot 1$, and $2 \cdot 1$.

The associations of airway hyperresponsiveness and a history of allergy with a higher prevalence of symptoms were independent of one another. The OR for airway hyperresponsiveness remained essentially the same after excluding a history of allergy from the logistic regression analysis.

To assess whether the associations between the exposure groups and a higher prevalence of symptoms was different for current smokers and non-smokers, or for hyperresponsive $v$ normally responsive subjects (effect modification), stratified analyses were performed. Subjects were defined as symptomatic if one or more respiratory symptoms (any symptom) was present. In the analysis stratified by smoking (table 4), the ORs for any symptom for smokers of the polyester vapour group was $2 \cdot 2$, of the oil mist and vapour group $1 \cdot 9$, and of the polyamide and polyester vapour group $4 \cdot 0$. In the unstratified analysis (table 3 ), these ORs were $1 \cdot 5,1 \cdot 6$, and $2 \cdot 3$. The ORs were smaller for non-smokers, suggesting that the difference from the reference group in prevalence of symptoms was greater for smokers than for non-smokers. In the analysis stratified by hyperresponsiveness (table 4), the ORs for any symptom for hyperresponsive subjects of the polyester vapour group was $0 \cdot 8$, of the oil mist and vapour group $1 \cdot 4$, and of the polyamide and polyester vapour group 1.9. The corresponding ORs for the normal responsive subjects were $2 \cdot 0,1 \cdot 8$, and $2 \cdot 5$. Thus the difference in prevalence of symptoms compared with the reference group was smaller for subjects with airway hyperresponsiveness than for subjects with normal airway responsiveness. These results might be explained because one or more respiratory symptoms was used as the definition of any symptom. Thus, an additional analysis was performed with two or more respiratory symptoms to define prevalence of symptoms. The exposure ORs for the hyperresponsive subjects were similar to or slightly larger than the ORs for the normally responsive subjects. For the hyperresponsive subjects the ORs of the polyester vapour group was $1.8(95 \% \mathrm{CI}$

Table 4 Estimated ORs (95\% CIs) for the prevalence of any symptom ( $n=176)$ by exposure group stratified by smoking habit and airway hyperresponsiveness

\begin{tabular}{|c|c|c|c|c|c|}
\hline \multirow[b]{2}{*}{$\begin{array}{l}\text { Exposure } \\
\text { group }\end{array}$} & \multicolumn{3}{|c|}{ ORs stratified by airway hyperresponsiveness } & \multicolumn{2}{|c|}{ ORs stratified by smoking } \\
\hline & $\begin{array}{l}\text { Non-smokers } \\
(n=147)\end{array}$ & $\begin{array}{l}\text { Ex-smokers } \\
(n=161)\end{array}$ & $\begin{array}{l}\text { Current smokers } \\
(n=360)\end{array}$ & $\begin{array}{l}\text { Airway hyperresp } \\
\text { No }(n=517)\end{array}$ & $\begin{array}{l}\text { zsiveness } \\
\text { Yes }(n=151)\end{array}$ \\
\hline $\begin{array}{l}\text { White collar } \\
\mathrm{SO}_{2}, \mathrm{SO}_{4}^{2-}, \mathrm{HCl} \\
\text { Polyester vapour } \\
\text { Oil mist and vapour } \\
\text { Polyamide and polyester vapour } \\
\text { Multiple exposures }\end{array}$ & $\begin{array}{l}\overline{0} \\
0 \cdot 4(0 \cdot 1-1 \cdot 5) \\
0 \cdot 2(0 \cdot 0-1 \cdot 7) \\
1 \cdot 2(0 \cdot 4-3 \cdot 9) \\
\overline{2 \cdot 6}(0 \cdot 4-17 \cdot 4)\end{array}$ & $\begin{array}{l}1 \cdot 1(0 \cdot 2-7 \cdot 1) \\
0 \cdot 2(0 \cdot 0-2 \cdot 5) \\
1 \cdot 6(0 \cdot 3-7 \cdot 8) \\
1 \cdot 3(0 \cdot 2-6 \cdot 6) \\
1 \cdot 3(0 \cdot 2-9 \cdot 7) \\
1 \cdot 9(0 \cdot 2-16 \cdot 1)\end{array}$ & $\begin{array}{l}1 \cdot 2(0 \cdot 5-3 \cdot 0) \\
0 \cdot 8(0 \cdot 4-1 \cdot 8) \\
2 \cdot 2(1 \cdot 0-4 \cdot 5)^{\star} \\
1 \cdot 9(1 \cdot 0-3 \cdot 6)^{\star} \\
4 \cdot 0(1 \cdot 7-9 \cdot 4)^{\star \star} \\
2 \cdot 7(0 \cdot 7-9 \cdot 4)\end{array}$ & $\begin{array}{l}1 \cdot 3(0 \cdot 5-3 \cdot 5) \\
0 \cdot 7(0 \cdot 2-1 \cdot 5) \\
2 \cdot 0(1 \cdot 0-4 \cdot 1) \\
1 \cdot 8(1 \cdot 0-3 \cdot 4) \\
2 \cdot 5(1 \cdot 1-5 \cdot 9)^{\star} \\
3 \cdot 2(1 \cdot 1-9 \cdot 2)^{\star}\end{array}$ & $\begin{array}{l}0.6(0 \cdot 2-2 \cdot 5) \\
0 \cdot 6(0 \cdot 2-1 \cdot 9) \\
0 \cdot 8(0 \cdot 3-2 \cdot 4) \\
1 \cdot 4(0 \cdot 5-3 \cdot 7) \\
1.9(0 \cdot 5-7 \cdot 3) \\
1 \cdot 7(0 \cdot 2-13 \cdot 1)\end{array}$ \\
\hline
\end{tabular}

${ }^{\star} \mathrm{p}<0.05 ;{ }^{\star \star} \mathrm{p}<0.01$

ORs are also adjusted for age and a history of allergy. 
$0 \cdot 4-8 \cdot 7)$, of the oil mist and vapour group $2 \cdot 1$ (95\% CI $0.5-8 \cdot 6)$, and of the polyamide and polyester vapour group $2.9(95 \%$ CI $0 \cdot 5-15 \cdot 8)$. For the normal responsive subjects these ORs were $1.0(95 \%$ CI $0.3-3.1), 1.5$ $(95 \%$ CI $0 \cdot 6-3 \cdot 7)$, and $3.0 \quad(95 \%$ CI $1 \cdot 0-9 \cdot 0)$. Thus the use of a more restrictive definition of presence of symptoms resulted in a stronger association between exposure and prevalence of symptoms for the hyperresponsive subjects.

The small numbers of subjects with a history of allergy in the various exposure groups did not allow a similar stratified analysis for subjects with or without a history of allergy.

The stratified analyses were also performed with adjustment for level of lung function, including $\% \mathrm{FEV}_{1}$ predicted as an independent variable. The associations between the exposure groups and the prevalence of symptoms remained the same.

To test whether the differences in ORs for the exposure groups between smokers and non-smokers and hyperresponsive and normally responsive subjects were significant, the logistic regression analyses of any symptom (one or more symptoms) were repeated including interaction terms. The analyses confirmed the stratified analyses. The ORs for the exposure group-smoking terms ranged from 1.5 to $8 \cdot 3$-indicated that the association between exposure group and a higher prevalence of symptoms was stronger for smokers than for non-smokers. The polyester vapour-smoking term was of borderline significance with an OR of $3.3(95 \%$ CI $0 \cdot 9-12 \cdot 1)$. The polyamide and polyester vapour-smoking term was significant with an OR of $8.3(95 \%$ CI $1 \cdot 3-51 \cdot 4)$. Including the exposure-airway hyperresponsiveness interaction terms caused a small increase in the exposure ORs. The ORs for the interaction terms did not reach significance and were, as was to be expected, less than $1 \cdot 0$, ranging from 0.4 to $0 \cdot 8$.

Exclusion of subjects from analyses might have influenced the study results. We repeated the logistic regression analysis with age, smoking habit, allergy history, and exposure group as independent variables, includ- ing and excluding 94 subjects of whom we did not have complete lung function data or histamine challenge data (28 subjects with different cultural or racial background not included). The magnitudes of the ORs for the exposure groups in these two analyses were similar.

\section{LUNG FUNCTION}

A first examination of the relation of level of lung function with smoking habit, airway responsiveness, history of allergy, respiratory symptoms, work related symptoms, and exposure group, was assessed by calculating the mean $\% F V C, \% F^{2} V_{1}$, and $\% M M E F$ of the predicted value for each subgroup. Smokers had significantly lower mean ${ }^{2} \mathrm{FEV}_{1}$ and mean \%MMEF values than the nonsmokers. Subjects with hyperresponsive airways and subjects with chronic respiratory. symptoms had significantly lower mean $\%$ FVC, $\% \mathrm{FEV}_{1}$, and $\% \mathrm{MMEF}$ than subjects with normal responsive airways and no chronic respiratory symptoms. The mean \% predicted lung function of subjects with and without a history of allergy and of subjects with and without work related symptoms, did not differ significantly. Compared with the reference group, the polyester vapour, the oil mist and vapour, and the polyamide and polyester vapour group had lower mean $\% \mathrm{FEV}_{1}$ and mean \%MMEF values. The $\mathrm{SO}_{2}$, the white collar group and the multiple exposure group had higher mean \% lung function values.

Multiple linear regression analyses were performed to estimate the association between the exposure groups and the level of lung function with simultaneous adjustment for potential confounding factors. With adjustment for age, length, and smoking habit the exposure groups were not significantly associated with a lower level of lung function (table 5, regression model 1). Adjustment for airway responsiveness and a history of allergy did not change these results (regression model 2). The results did not change with adjustment for chronic respiratory symptoms (regression model 3). The MMEF was lower for the $\mathrm{SO}_{2}(-73 \mathrm{ml} / \mathrm{s})$, the polyester vapour

Table 5 Regression coefficients ( $\beta$ ) and standard errors (SEs) for FEV 1 and MMEF: the coefficients are adjusted for age, age ${ }^{2}$, and height

\begin{tabular}{|c|c|c|c|c|c|c|c|c|c|c|c|c|}
\hline & \multicolumn{6}{|c|}{$F E V_{1}(m l)$} & \multicolumn{6}{|c|}{$M M E F(\mathrm{ml} / \mathrm{s})$} \\
\hline & \multicolumn{2}{|c|}{ Model 1} & \multicolumn{2}{|c|}{ Model 2} & \multicolumn{2}{|c|}{ Model 3} & \multicolumn{2}{|c|}{ Model 1} & \multicolumn{2}{|c|}{ Model 2} & \multicolumn{2}{|c|}{ Model 3} \\
\hline & $\beta$ & $S E$ & $\beta$ & $S E$ & $\beta$ & $S E$ & $\beta$ & $S E$ & $\beta$ & $S E$ & $\beta$ & $S E$ \\
\hline $\begin{array}{l}\text { Exposure groups: } \\
\text { White collar } \\
\mathrm{SO}_{2} \mathrm{SO}_{4}{ }^{2-}, \mathrm{HCl} \\
\text { Polyester vapour } \\
\text { Oil mist and vapour } \\
\text { Polyamide and polyester vapour } \\
\text { Multiple exposures } \\
\text { Pack-years } \\
\text { Airway hyperresponsiveness } \\
\text { Allergy } \\
\text { Any symptom } \ddagger\end{array}$ & $\begin{array}{l}34 \\
53 \\
-67 \\
9 \\
-3 \\
38 \\
-8 \\
- \\
-\end{array}$ & $\begin{array}{l}94 \\
68 \\
73 \\
64 \\
93 \\
124 \\
3^{\star \star} \\
- \\
-\end{array}$ & $\begin{array}{l}33 \\
34 \\
-55 \\
-18 \\
-15 \\
26 \\
-7 \\
-298 \\
-25 \\
-\end{array}$ & $\begin{array}{l}78 \\
57 \\
61 \\
54 \\
77 \\
103 \\
3 \star \star \\
45^{\star \star} \\
57 \\
-\end{array}$ & $\begin{array}{l}30 \\
21 \\
-45 \\
-4 \\
9 \\
55 \\
-5 \\
-271 \\
1 \\
-173\end{array}$ & $\begin{array}{l}77 \\
56 \\
60 \\
53 \\
76 \\
102 \\
3^{\star} \\
45^{\star \star} \\
55^{\star \star} \\
43^{\star \star}\end{array}$ & $\begin{array}{l}143 \\
11 \\
-115 \\
-65 \\
-62 \\
106 \\
-12 \\
= \\
-\end{array}$ & $\begin{array}{l}196 \\
142 \\
153 \\
134 \\
192 \\
257 \\
6+ \\
= \\
-\end{array}$ & $\begin{array}{l}134 \\
-48 \\
-81 \\
-145 \\
-95 \\
46 \\
-9 \\
876 \\
72 \\
-\end{array}$ & $\begin{array}{l}187 \\
135 \\
146 \\
128 \\
183 \\
246 \\
6 \\
107^{\star \star} \\
133 \\
-\end{array}$ & $\begin{array}{l}128 \\
-73 \\
-61 \\
-117 \\
-47 \\
103 \\
-5 \\
-825 \\
121 \\
-336\end{array}$ & $\begin{array}{c}186 \\
135 \\
145 \\
128 \\
183 \\
245 \\
6 \\
108^{\star \star} \\
133 \\
104^{\star \star}\end{array}$ \\
\hline
\end{tabular}


$(-61 \mathrm{ml} / \mathrm{s})$, the oil mist and vapour $(-117$ $\mathrm{ml} / \mathrm{s}$ ) and the polyamide and polyester vapour group $(-47 \mathrm{ml} / \mathrm{s})$, but these differences were not significant.

Smoking expressed as pack-years was significantly associated with lower FVC ( -8 $\mathrm{ml} / \mathrm{y}), \mathrm{FEV}_{1}(-8 \mathrm{ml} / \mathrm{y})$, and MMEF (-12 $\mathrm{ml} / \mathrm{s}$ y; $\mathrm{p}=0.054)$ values. The levels of significance decreased after adjustment for airway hyperresponsiveness and respiratory symptoms (table 5). Airway hyperresponsiveness was significantly associated with lower FEV 1 and MMEF, but not significantly with FVC $(-49 \mathrm{ml} ; \mathrm{p}=0.37)$. A history of allergy was not significantly associated with a decreased lung function (regression model 2 ; all $p$ values $>0 \cdot 2$ ).

To investigate whether there was a difference in the association between exposure groups and level of lung function for smokers compared with non-smokers, for hyperresponsive $v$ normally responsive subjects and for subjects with and without a history of allergy, we performed linear regression analyses stratified by each of these characteristics. These analyses showed no indication of a possible interaction between exposure to irritants and current smoking, airway hyperresponsiveness, and the presence of a history of allergy.

To investigate whether the duration of employment in the current exposure group was associated with a lower level of lung function, the multiple regression analyses stratified by four duration categories: $\leqslant 2$, $>2-\leqslant 5,>5-\leqslant 10$, and $>10$ years of exposure. In the first three catagories, the exposure groups were not significantly associated with a lower level of lung function. In the category with $>10$ years of exposure, however, all exposure groups had lower FVC (ranging from $-110 \mathrm{ml}$ to $-197 \mathrm{ml}$ ), $\mathrm{FEV}_{1}$ (ranging from $-121 \mathrm{ml}$ to $-358 \mathrm{ml}$ ), and MMEF values (ranging from $-354 \mathrm{ml} / \mathrm{s}$ to -1247 $\mathrm{ml} / \mathrm{s}$ ). The oil mist and vapour group had a significantly lower mean $\mathrm{FEV}_{1}(-358 \mathrm{ml})$ and MMEF ( $-1247 \mathrm{ml} / \mathrm{s})$. For the polyester vapour group the $\mathrm{FEV}_{1}$ was not significantly lower $(-295 \mathrm{ml}, \mathrm{p}=0.14)$ but the MMEF was significantly lower $(-1080 \mathrm{ml} / \mathrm{s})$.

Exclusion of subjects from the analyses might have influenced the results. We therefore repeated the overall analyses, including
66 subjects of whom we had a complete data set but no histamine challenge data. No obvious differences were noted in the associations between the exposure groups and the level of lung function, compared with the analyses that excluded these 66 subjects. For the analyses stratified by the duration of exposure, including the 66 subjects changed the associations between exposure groups and level of lung function in the category with $>10$ years of exposure, but not in the other exposure categories. In the category with $>10$ years of exposure, the polyester vapour and the oil mist and vapour group were still associated with a lower level of lung function, but these associations were no longer statistically significant (table 6). Of the 66 excluded subjects $18(27 \%)$ had $>10$ years of exposure and 10 of these 18 subjects belonged to the reference group. Excluding these 18 subjects resulted in an increase in the mean level of lung function (for example, $\mathrm{FEV}_{1}$ increased from $102 \%$ to $106 \%$ ), and this increase was greatest in the reference group (for example, $\% \mathrm{FEV}_{1}$ increased from $103 \%$ to $112 \%$ ). Thus by excluding these subjects, the differences between the workers with $>10$ years exposure of the reference group and the exposed groups increased.

\section{Discussion}

Exposure to irritants, as encountered in this study, was associated with a higher prevalence of respiratory symptoms but not with a lower mean FVC, $\mathrm{FEV}_{1}$, and MMEF. The workers of the polyester vapour and the oil mist and vapour group with more than 10 years of exposure had lower lung function values than the reference group. Stratified analyses showed that the association between the polyester vapour and polyamide and polyester vapour group and the prevalence of respiratory symptoms was greater for smokers than for non-smokers. The association between exposure to irritants and respiratory symptoms was smaller for subjects with airway hyperresponsiveness than for subjects with normal airway responsiveness.

In the synthetic fibre plants under study, workers are exposed to a mixture of airway irritants. In addition to the multiple exposure, workers are exposed to high environmental

Table 6 Regression analyses of the population with ever 10 years exposure

\begin{tabular}{|c|c|c|c|c|c|c|c|c|}
\hline \multirow[b]{3}{*}{ Exposure group } & \multicolumn{4}{|c|}{$F E V_{1}:$ subjects with no histamine challenge data } & \multicolumn{4}{|c|}{ MMEF: subjects with no histamine challenge data } \\
\hline & \multicolumn{2}{|c|}{$\begin{array}{l}\text { Included } \\
(n=81)\end{array}$} & \multicolumn{2}{|c|}{$\begin{array}{l}\text { Excluded } \\
(n=63)\end{array}$} & \multicolumn{2}{|c|}{$\begin{array}{l}\text { Included } \\
(n=81)\end{array}$} & \multicolumn{2}{|l|}{$\begin{array}{l}\text { Excluded } \\
(n=63)\end{array}$} \\
\hline & $\begin{array}{l}\beta \\
(m l)\end{array}$ & $S E$ & $\begin{array}{l}\beta \\
(m l)\end{array}$ & $S E$ & $\begin{array}{l}\beta \\
(\mathrm{ml} / \mathrm{s})\end{array}$ & $S E$ & $\begin{array}{l}\beta \\
(\mathrm{ml} / \mathrm{s})\end{array}$ & $S E$ \\
\hline White collar & 129 & 212 & -1 & 217 & $\underline{168}$ & 526 & 49 & 578 \\
\hline $\begin{array}{l}\text { Polyester vapour } \\
\text { Oil mist and vapour } \\
\text { Polyamide and polyester vapour } \\
\text { Multiple exposures }\end{array}$ & $\begin{array}{l}-175 \\
-159 \\
156 \\
192\end{array}$ & $\begin{array}{l}206 \\
185 \\
205 \\
232\end{array}$ & $\begin{array}{l}-361 \\
-465 \\
-71 \\
-60\end{array}$ & $\begin{array}{l}206 \dagger \\
189^{\star} \\
216 \\
228\end{array}$ & $\begin{array}{l}-898 \\
-906 \\
58 \\
140\end{array}$ & $\begin{array}{l}511 \dagger \\
459 \dagger \\
509 \\
577\end{array}$ & $\begin{array}{l}-1236 \\
-1495 \\
-185 \\
-408\end{array}$ & $\begin{array}{l}550^{\star} \\
504^{\star \star} \\
575 \\
608\end{array}$ \\
\hline
\end{tabular}


temperatures near the machines at some places, which may interact with exposure to irritants. ${ }^{9}$ Most of the measured (and known) vapour concentrations are lower than the Dutch threshold limit values (TLVs) with the exception of diphenyl diphenyloxide and possibly lactam. For the polyester vapour group, personal exposure to diphenyl diphenyloxide seems to be occasionally high compared with the Dutch TLV of $7 \mathrm{mg} / \mathrm{m}^{3}$. The Dutch TLV is mainly based on unpleasant odour perception. Irritation of the eyes and the mucous membranes have been reported for exposures of 19 to $25 \mathrm{mg} / \mathrm{m} \cdot{ }^{31617}$ For the polyamide and polyester vapour group personal exposure to lactam vapour could reach the Dutch TLV of $20 \mathrm{mg} / \mathrm{m}^{3}$. Lactam vapour can cause throat irritation and cough. ${ }^{18}$ One of the most suspected thermodegradation products of polyester is acetaldehyde. Acetaldehyde can cause hypersecretion of the upper respiratory tract and bronchial mucus. ${ }^{19}$ Personal exposure measurements showed low concentrations of acetaldehyde compared with the Dutch TLV of $180 \mathrm{mg} / \mathrm{m}^{3}$. We also found that the level of exposure was independent of function tasks: the acetaldehyde exposure of production floor managers and production line workers of the oil mist and vapour group and the polyamide and polyester vapour group were similar. This means that acetaldehyde was measured, irrespective of polyester vapour exposure. Thus exposure to aldehyde was not a marker for exposure to polyester vapour. A possible explanation for the low homogeneous acetaldehyde exposure is that the measured acetaldehyde emanated from tobacco smoke. ${ }^{20}$ On average, the workers of the oil mist and vapour group and the polyamide and polyester vapour group, smoke a considerable amount when they are not working at the machines.

The engineers who are responsible for the maintenance and cleaning of the machines are more likely to have short term high exposures than production line workers. Moreover, interviews showed that they are also exposed to varying environmental temperatures. Engineers reported significantly more episodes of bronchitis but not more of the other symptoms. It is possible that as well as irritant exposure, the varying environmental temperatures could contribute to a high prevalence of episodes of bronchitis.

Low level exposure to airway irritant is associated with a higher prevalence of respiratory symptoms. Chan-Yeung and coworkers reported more cough, phlegm, and wheeze in 797 aluminium smelter workers exposed to low concentrations of hydrogen fluoride $(0.48$ $\mathrm{mg} / \mathrm{m}^{3}$, eight hour time weighted average) and $\mathrm{SO}_{2}\left(2.0 \mathrm{mg} / \mathrm{m}^{3}\right.$, eight hour time weighted average).$^{21}$ Osterman and coworkers showed in a health study in 145 silicon carbide production workers that the prevalence of symptoms such as phlegm, wheeze, and dyspnoea were significantly and dose-dependently related to $\mathrm{SO}_{2}$ measured cumulatively, or by average $\mathrm{SO}_{2}$ exposure while employed. They reported mean current exposure to $\mathrm{SO}_{2}$ of $0.69 \mathrm{mg} / \mathrm{m}^{3}$ (eight hour time weighted average), which is low, but $20 \%$ of the workers had daily exposure to $\mathrm{SO}_{2}$ of $2 \cdot 7-4 \cdot 0$ $\mathrm{mg} / \mathrm{m}^{3}{ }^{22}$ Experimental studies with volunteers showed that exposure to $2.66 \mathrm{mg} / \mathrm{m}^{3}$ $\mathrm{SO}_{2}(=1 \mathrm{ppm})$ can cause acute falls in $\mathrm{FEV}_{1}$, $\mathrm{FEF}_{50 \%}$, and $\mathrm{FEF}_{75 \%}{ }^{23}$ and that asthmatic, non-allergic subjects are much more sensitive to the effect of inhaled $\mathrm{SO}_{2}$ than non-asthmatic, non-allergic subjects. ${ }^{23}{ }^{24}$ This susceptibility of asthmatic persons to exposure to $\mathrm{SO}_{2}$ was the reason why the company did not employ subjects with a suspected history of asthma like symptoms in the para-aramide plant, because of the possible exposure to $\mathrm{SO}_{2}$ and $\mathrm{SO}_{4}{ }^{2-}$. This was done ever since the para-aramide fibre came into production in 1984. The low prevalence of chronic respiratory symptoms and of the airway hyperresponsiveness in the $\mathrm{SO}_{2}$ group are probably due to this pre-employment selection. As well as selection, the maximum exposure duration of only four and a half years at the time of the survey may contribute to the low prevalence of respiratory symptoms and to the fact that the mean level of lung function did not differ from the reference group.

A higher symptom prevalence in workers exposed to oil mist has also been reported by others. Robertson and coworkers reported current asthmatic symptoms in 25 patients due to various oil mists. ${ }^{25}$ Järvholm and coworkers found a higher prevalence of cough and phlegm in 164 metal workers exposed to mineral and emulsified oil mist. ${ }^{28}$ It remains unclear whether in our study the association between exposure to oil and respiratory symptoms is due only to oil exposure. The spindraw winders were also exposed to airborne microorganisms and endotoxins, although the measured concentrations were low. ${ }^{11}$ Although Järvholm and coworkers found respiratory symptoms, they did not find differences in FVC and $F E V_{1}$ between the exposed metal workers and non-exposed office workers. The minimum duration of exposure was three years. ${ }^{28}$ Also in other cross sectional studies, no association was found between exposure to oil mist and lower levels of lung function. ${ }^{27}{ }^{28}$ Kennedy and coworkers found acute $\mathrm{FEV}_{1}$ falls during the working days among 89 car workers exposed to oil mist, but no falls in $\mathrm{FEV}_{1}$ occurred over the course of the working week. At the beginning of the working week, no differences were found in $\mathrm{FEV}_{1}$ between exposed machinists ( $n=89$ ) and the controls (assemblers; $n=$ 42). All workers had worked for at least five years for the company and all workers performed the same job in the same area for at least six months. These authors concluded that the results of the cross sectional lung function data may have been biased because non-participants had lower lung function than the participants, and workers who had respiratory symptoms might have left the company within five years of employment. ${ }^{29}$ Thus in a cross sectional study of a working force, selection bias, such as self selection and pre-employment selection $\left(\mathrm{SO}_{2}\right.$ group in this 
study) may explain a finding of no association between exposure and a lower lung function, ${ }^{29} 30$ and may underestimate the association between exposure and prevalence of symptoms. As well as selection, our findings may also have been biased by the fact that some workers from the current reference group have an occupational work history at other departments. Moreover, the exposure level within each exposure group may differ. Within the polyester vapour, the oil mist and vapour, and the polyamide and polyester vapour group, workers can have different main function tasks, resulting in personal exposure differences. For the $\mathrm{SO}_{2}$ group the personal exposure may differ from time to time because certain function tasks were rotated.

In our study, current smoking modified the association between the polyester vapour and polyamide and polyester vapour group and respiratory symptoms. Osterman and coworkers also found that the association between exposure to $\mathrm{SO}_{2}$ and respiratory symptoms was greater in smokers than in current nonsmokers. ${ }^{22}$ Studies in general populations did not show significant interactions between current smoking and either dust or fume exposure on prevalence of symptoms. ${ }^{831}$ In our study, it remains unclear whether there was really an interaction between smoking and exposure to irritants or whether the numbers of the never and ex-smokers are just too small. Anyhow, the stratified analyses showed for the smokers a more accurate estimation of the association between exposure group and the prevalence of symptoms than the unstratified analyses.

An explanation for smaller ORs for the exposure group of the hyperresponsive subjects compared with the ORs of the normally responsive subjects (table 4), may be that subjects with airway hyperresponsiveness and symptoms have not been employed at all or have left their jobs. In occupational health surveillance, the presence of airway hyperresponsiveness in workers can be an exclusion criterion for employment. In our study population it was, as mentioned before, an exclusion criterion for employment in the production plant of the para-aramid fibres (the $\mathrm{SO}_{2}$ group), and to a lesser degree also for employment in the industrial yarn plant (oil mist and vapour group). In the years 1984-9 the medical department of the synthetic fibre plant had a tendency not to employ subjects with a history of asthma like symptoms as spin-draw-winders. This was done because respiratory problems had been reported by some workers, which were suspected to be work related. For employment in the production departments of the other exposure groups, no such respiratory health criteria were applied.

In general, allergy may be associated with increased risk of developing chronic airway obstruction and chronic symptoms. ${ }^{32} \mathrm{~A}$ history of allergy was an important predictor of prevalence of respiratory symptoms, but not of a lower level of lung function, although
$34 \%$ of the allergic subjects had airway hyperresponsiveness. Also Fletcher and coworkers did not find an association in a male working population between a history of allergy and the $\mathrm{FEV}_{1}{ }^{33}$ Population based data indicate a decreasing prevalence of allergy after the age of $40 .{ }^{34}$ Thus because of the relatively young age of our population ( $76 \%$ younger than 40 ) the role of allergy in the prevalence of symptoms may be greater than in older populations. In the current study, a history of allergy is assessed on the basis of the self reported estimate of being allergic and this estimate may be less reliable than positive skin tests to common airborne allergens. Thus the association between allergy and symptoms may differ from studies in which allergy is defined on the basis of positive skin tests to common airborne allergens.

Although our study results may have been biased by factors as mentioned in this discussion, it might also be possible that exposure to irritants at levels commonly found in industrial settings, does not lead to an increased loss of pulmonary function or only to a lesser degree. A study in a general population and in an occupational population, showed that exposure to gases or fumes was associated with a lower lung function only in the presence of simultaneous exposure to heat or dust. ${ }^{89}$ Osterman and coworkers studied silicon carbide production workers, and found that respiratory symptoms were associated with low exposure to $\mathrm{SO}_{2}$, but that a lower lung function was not associated with $\mathrm{SO}_{2}$ but with exposure to dust. $^{22} 35$ In our study, workers who are exposed to irritants are not simultaneously exposed to airborne dust. Although the evidence of an association between occupational exposures to gases, vapours, fumes and a lower lung function, is not consistent, ${ }^{6}$ occupational studies do report that there is an association between these agents and a higher prevalence of chronic respiratory symptoms. ${ }^{8}$ 222635 Our study is in agreement with these findings.

In conclusion, our findings show that exposure to multiple airway irritants encountered in these synthetic fibre plants is, compared with a reference group, associated with a higher prevalence of chronic respiratory symptoms. This association was seen most clearly in the workers who smoke. Our study could not show an overall association between the irritant exposure and a lower level of lung function. The results indicate that workers with more than 10 years exposure to polyester vapour and to oil mist and vapour have a decreased lung function. Furthermore, we found no indication of a possible interaction between exposure to airway irritants, airway hyperresponsiveness, current smoking, or a history of allergy on level of lung function. We agree with Becklake $^{6}$ that further investigation is needed to clarify the relation between occupational exposure to low concentrations of irritants and respiratory health problems in the absence of exposure to airborne dust. 
We thank all the workers of the synthetic fibre plants who participated for their cooperation, the employees of the Occupational Health Department for their extra efforts, the members of the survey team Mr F de Wolff and Mrs of Wageningen and the student of the University of Nijmegen for their efforts in taking exposure measurements. Dr J G R de Monchy of the University Hospital, Groningen for his support in developing the histamine protocol, Mr R Stigter and Mrs J Veltman for help with statistics, and SensorMedics BV for the lung function apparatus.

This work was supported by grant No 88-32 of The Netherlands Asthma Fund.

1 Chan-Yeung M, Lam S. Occupational asthma. Am Rev Respir Dis 1986;133:668-703.

2 Vedal $S$, Chan-Yeung $M$. Airway responsiveness and atopy in occupational airways disease. In: Weis ST, Sparrow D, eds. Airway responsiveness and atopy in the development of chronic lung disease. New York: Raven Press, 1989;271-92.

3 Brooks SM, Weiss MA, Bernstein IL. Reactive airways dysfunction syndrome. 7 Occup Med 1985;27:473-6.

4 Cockcroft DW. Airway hyperresponsiveness: therapeutic implications. Ann Allergy 1987;59:405-14.

5 Sluiter HJ, Koëter GH, Monchy JGR de, Postma DS, Vries K de, Orie NGM. The Dutch hypothesis (chronic non-specific lung disease) revisited. Eur Respir $\mathcal{f}$ 1991;4:479-89.

6 Becklake MR. Occupational exposures: evidence for a causal association with chronic obstructive pulmonary disease. Am Rev Respir Dis 1989;140:S85-91.

7 Brooks SM, Kalica AR. Strategies for elucidating the relationship between occupational exposures and chronic air-flow obstruction. Am Rev Respir Dis 1987; 135:268-73.

8 Korn RJ, Dockery DW', Speizer FE, Ware JH, Ferris BG Occupational exposures and chronic respiratory symptoms. Am Rev Respir Dis 1987;136:298-304

9 Kauffmann F, Drouet D, Lellouch J, Brille D. Occupational exposure and 12-year spirometric changes Occupational exposure and 12-year spirometric changes among $221-32$.

10 Higgens $M$. Epidemiology of COPD: state of the art Chest 1984;85:3S-8.

11 Kateman E, Heederik D, Pal TM, Smeets M. Smid T, Spitteler M. Relationship of airborne microorganisms with the lung function and leucocyte levels of worker with a history of humidifier fever. Scand $\mathcal{F}$ Work Environ Health 1990;16:428-33.

12 Quanjer PhH. Standardized lung function testing. Report of the Working Party "Standardization of Lung Function Tests". Bulletin Européen de Physiopathologie Respiratoire 1983;(suppl 5):1-95.

13 Vries, K de, Goei JT, Booy-Noord H, Orie NGM. Changes during 24 hours in the lung function and histamine hyperreactivity of the bronchial tree in asthmatic and bronchitic patients. Int Arch Allergy 1962;20: a3 101 .

14 Buist SA. Evaluation of lung function; concepts of normality. In: Simmons DH, ed. Current pulmonology. New York: Wiley and Sons, 1982;141-65.

15 Sparrow D, Weiss ST. Background. In: Weiss ST, Sparrow D, eds. Airway responsiveness and atopy in the development of chronic lung diseases. New York: Raven Press, 1989;1-21.

16 Sandmeyer EE. Aromatic hydrocarbons. In: Clayton GD Clayton FE, eds. Patty's industrial hygiene and toxicology, 3rd ed. New York: John Wiley \& Sons, Inc 1982; 3325-31

17 Hefner RE, Leong BKJ, Kociba RJ, Gehring PJ. Repeated inhalation toxicity of diphenyl oxide in experimental animals. Toxicol Appl Pharmacol 1975;33:78-86.

18 Ferguson WS, Wheeler DD. Caprolactam vapor exposures. Am Ind Hyg Assoc f 1973;34:384-9.

19 Parkes WR. Occupational lung diseases. 2nd ed. London Butterworth, 1982;472.

20 IARC. Monographs on the evaluation of the carcinogenic risk of chemicals to human. Alkyl compounds, aldehydes. epoxides and peroxides. Lyon: International Agency for Research on Cancer. 1985; vol36.

21 Chan-Yeung M, Wong R, MacLean L, Tan F, Schulzer $\mathrm{M}$, Enarson $\mathrm{D}$, et al. Epidemiologic health study of $\mathrm{M}$, Enarson $\mathrm{D}$, et al. Epidemiologic health study of Am Rev Respir Dis 1983;127:465-9.

22 Osterman JW, Greaves IA Smith TJ, Hammond SK Robins JM, Thériault G. Respiratory symptoms associated with low level sulphur dioxide exposure in silicon carbide production workers. $B r \mathcal{F}$ Ind Med 1989;46: 629-35.

23 Koenig JQ, Pierson WE, Horike M, Frank R. Effects of inhaled sulfur dioxide $\left(\mathrm{SO}_{2}\right)$ on pulmonary function in healthy adolescents: exposure to $\mathrm{SO}_{2}$ or $\mathrm{SO}_{2}+$ sodium chloride droplets aerosol during rest and exercise. Arch Environ Health 1982;37:5-9.

24 Sheppard D, Wong WS, Uehara CF, Nadel JA, Boushey HA. Lower threshold and greater bronchomotor responsiveness of asthmatic subjects to sulfur dioxide. responsiveness of asthmatic subject

25 Robertson AS, Weir DC, Burge PS. Occupational asthma due to oil mist. Thorax 1988;43:200-5.

26 Jävholm B, Bake B, Lavenius B, Thiringer G, Vokmann $R$. Respiratory symptoms and lung function in oil mistexposed workers. F Occup Med 1982;24:473-9.

27 Ely TS, Pedley SF, Hearne FT, Stille WT. A study of mortality, symptoms and respiratory function in human exposed to oil mist. F Occup Med 1970;12:253-61.

28 Oxhoj H, Andreasen H, Meyer-Henius U. Respiratory symptoms and ventilatory lung function in machine shop workers exposed to colant-lubricants. European Fournal of Respiratory Diseases 1982;S118:85-9.

29 Kennedy SM, Greaves IA, Kriebel D, Eisen EA, Smith TJ, Woskie SR. Acute pulmonary responses among automobile workers exposed to aerosols of machining automobile workers exposed to aerosol

30 Gamble JF, McMichael AJ, Williams T, Battigelli M Respiratory function and symptoms: an environmentalepidemiological study of rubber workers exposed to a phenol-formaldehyde type resin. Am Int Hyg Assoc $\mathcal{f}$ 1976;37:499-513.

31 Viegi G, Prediletto R, Paoletti P, Carrozzi L, Di Pede F et al. Respiratory effects of occupational exposure in general population sample in North Italy. Am Rev Respir Dis 1991;143:510-5.

32 Weiss ST, O'Connor GT, Sparrow D. The role of allergy and airway responsiveness in the natural history of chronic airflow obstruction (CAO). In: Weiss ST, Sparrow D, eds. Airway responsiveness and atopy in the development of chronic lung disease. New York: Raven Press, 1989:181-240.

33 Fletcher C, Peto R, Tinker C, Speizer FE. The natural history of bronchitis and emphysema Oxford: Oxford history of bronchitis and

34 Burrows B. Distribution of allergy in the general population. In: Sluiter HJ, van der Lende R, eds. Bronchitis $I V$. Assen: Van Gorcum, 1989;3-10.

35 Osterman JW, Greaves IA, Smith TJ, Hammond SK Robins JM, Thériault G. Work related decrement in pulmonary function in silicon carbide production workers. Brf Ind Med 1989;46:708-16. 